\title{
Land Degradation in the Sudan Savanna of Ghana: A Case Study in the Bawku Area
}

\author{
J. K. Senayah ${ }^{1 *}$, S. K. Kufogbe ${ }^{2}$ and C. D. Dedzoe ${ }^{1}$ \\ ${ }^{1}$ CSIR-Soil Research Institute, Kwadaso-Kumasi, Ghana \\ ${ }^{2}$ Department of Geography and Resource Development, University of Ghana, Legon \\ *Corresponding author
}

\begin{abstract}
The study was carried out in the Bawku area, which is located within the Sudan savanna zone. The study examined the physical environment, human factor and the interactions between them so as to establish the degree and extent of land degradation in the Bawku area. Six rural settlements around Bawku were studied with data on soils collected along transects. Socio-economic information was collected by interviewing key informants and through the administration of questionnaires. Land degradation in the area is the result of interaction between the physical and human environments. Physical environmental characteristics influencing land degradation include soil texture, topography and rainfall. The soils in the study area are developed over granite and Birrimian phyllite. In the granitic areas soil texture is an important factor, while in the Birrimian area, it is the steep nature of the terrain that induces erosion. The granitic soils are characteristically sandy and, as such, highly susceptible to erosion. Topsoil $(10-30 \mathrm{~cm})$ sand contents of three major soils developed over granite are over $80 \%$. Severe erosion has reduced topsoil thickness by over $30 \%$ within a period of 24 years. Rainfall, though generally low ( $<1000 \mathrm{~mm}$ ), falls so intensely to break down soil aggregates thus accelerating erosion. Other observed indicators of land degradation include sealed and compacted topsoils, stones, gravel, concretions and iron pan. The major human activities that affect the physical environment are farming and domestic energy production. Associated practices such as land clearing for farming, total crop harvesting, burning of organic material during land preparation and inadequate manure application aggravate the degradation problem. These activities destroy the soil physical and chemical properties, thus, resulting in nutrient-depleted soils. A major effect is a progressive decline in crop yields as confirmed by $94 \%$ of 210 respondents.
\end{abstract}

\section{Introduction}

Land degradation is an issue of worldwide concern as it threatens global food security and environmental quality. It is an acute problem in Africa where deforestation, overgrazing and mismanagement of land resources have rendered over 320 million hectares of land unsuitable for any meaningful agriculture (Sant 'Anna, 1993, 2001; Sherr \& Yadav, 1996). The most common form of degradation is soil erosion by water and wind, which results from vegetation removal with negative conse-quences for soil productivity (Oldeman, 1994).

In sub-Saharan Africa, the majority of the soils in the arid and semi-arid areas are Arenosols, Lixisols, Regosols, Leptosols and Plinthosols, which are characteristically light-textured and inherently low in natural fertility, poor in structure, low organic matter and have low buffering capacity (Agboola \& Aiyelari, 2000; Asiamah, Quansah \& Dedzoe, 2000; Sant 'Anna, 2001). These characteristics make more than $60 \%$ of the soils highly susceptible to accelerated erosion due to various types of soil mismanagement without any investment in improved conservation measures (Agboola \& Aiyelari, 2000). Several studies (Norton et al., 1998; Lowery et al., 1998; Lal, Mokma \& Lowery, 1998; Olson et al., 1998) have shown that accelerated erosion has an adverse effect on soil quality and its agronomic productivity.

In a GLASOD study (Sherr, 1999) soil chemical degradation, through loss of nutrients including organic matter, was ranked second to soil erosion. Nutrient depletion occurs mainly through crop removal in harvested crops and residues, leaching, erosion, burning and nitrogen volatilization. For sub-Saharan Africa, Stoorvogel \& Smaling (1990) estimate depletion rates for the major nutrients as $22-26 \mathrm{~kg} \mathrm{~N}, 6-7 \mathrm{~kg} \mathrm{P}_{2} \mathrm{O}_{5}$ and $18-23 \mathrm{~kg} \mathrm{~K} \mathrm{O}_{2} \mathrm{~kg}$ per hectare per year between 1983-2000. In Ghana, the estimates for 2000 were $35 \mathrm{~kg} \mathrm{~N}, 4 \mathrm{~kg} \mathrm{P}_{2} \mathrm{O}_{5}$ and $20 \mathrm{~kg} \mathrm{~K}_{2} \mathrm{O}$ (Asiamah, Quansah \& Dedzoe,2000). These losses have reduced soil productivity, thus, leading to declining food production, food insecurity, reduced farm family incomes and livelihoods, slow economic growth against the background of increasing population and urbanization (Shetty, Debrah \& Renard, 1995).

In Ghana, the most susceptible agro-ecological zone to degradation is the interior savanna, which covers about $50 \%$ of the land area of the country (UNSO, 1986; Asiamah, Quansah \& Dedzoe, 2000). It comprises the Guinea and Sudan savanna zones. In these environments, especially the Sudan savanna agro-ecological zone, the tradi-tional systems of soil fertility re-storation such as shifting cultivation and nomadic grazing, have broken down because the potential carrying capacity of the land has been exceeded (Asiamah, Quansah \& Dedzoe., 2000; Sant 'Anna, 2001), thus, resulting in the use of marginal and non-productive agricultural lands with serious degradation problems (Asiamah \& Quansah, 1992) such as livestock overgrazing, reduced and erratic rainfall, low quality pasture and fodder and inadequate quality and quantity of manure for soil fertility restoration (Rhodes, 1993).

A study carried out in the Bawku area, which lies in the Sudan savanna agro-ecological zone of Ghana, shows that degradation is accelerated mainly by high population pressure with population density being 200 persons $/ \mathrm{km}^{2}$ (DGRD, 1992). The paper presents a study carried out in selected communities in the Bawku area. It examines the physical environment, the human factor and the interactions between these with respect to land degradation in these communities. This will provide a clear understanding of the nature and extent of land degradation in the area, which 
can facilitate the development of strategies for solving soil degradation and its associated problems not only in the Bawku area but also in similar environments within the Sudan savanna agro-ecological zone of Ghana.

\section{Materials and methods}

The study area is located in six rural commu-nities around Bawku., in the Bawku District (Fig. 1). The communities are Yumboku/Goseesi, Bulugu, Zawse, Bansi, Tusongu/Mognori and Manga/Nyorugu. The com-munities were selected on the basis of terrain characteristics and differences in soil surface conditions.

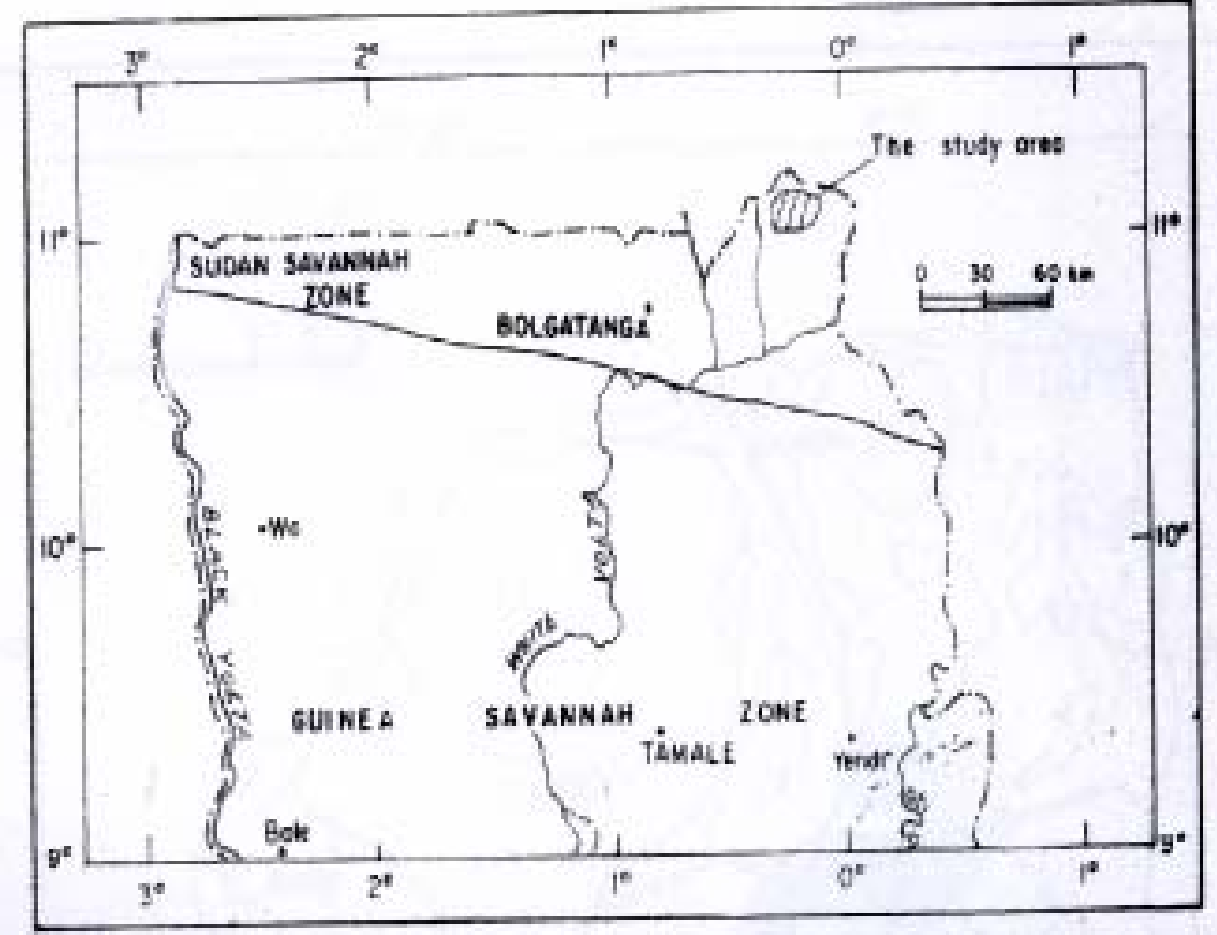

Fig. 1. Location of the study area in the Bawku District

Secondary data on soils in the area were obtained from a detailed-reconnaissance soil survey report $(1: 250,000)$ of the Navrongo-Bawku region (Adu, 1969). With this as baseline data, further observations were made from minipits dug at 100-m intervals along transects laid on major soil units. The parameters examined were topsoil thickness and soil surface conditions in terms of rocks, gravel, concretions and iron-pan. Particle size distribution of the soils was determined using the method of Bouyoucous (1962). Soil samples taken at two depths $(0-10 \mathrm{~cm}$ and $10-30 \mathrm{~cm})$ from 14 randomly selected farms in the communities were analyzed for the following key fertility parameters: organic carbon by modified Walkley-Black method (Nelson \& Sommers, 1982); total nitrogen by modified Kjeldahl digestion and distillation (van Reeuwijk, 1986); available phosphorus and available potassium were determined in Bray's No. 1 extract. Phosphorus in the ex-tract was determined by spectrophotometry and potassium by flame photometry. This was to determine the fertility status of the soils under indigenous cultivation practices and find out how this is impacting on land degradation in the area. Participa-tory rural appraisal (PRA) tools, such as key infor-mants, groups and semi-structured inter-views, historical accounts, observations and transect walks were used to gather informa-tion on land use practices, changes in crop yields and major domestic energy sources. The observed physical indicators of degradation in the selected communities were mapped at a scale of 1:200,000 to establish their distribution, extent and, consequently, the severity of land degrada-tion in the study area.

\section{Soils and topography}

\section{Results and discussion}

The soils are developed from granites and lower Birrimian phyllites. These broad units differ in terms of soil and topographical characteristics. These differences are re-flected in the major influences on degra-dation and the resulting features. Over granite, topography is generally gently undulating with slopes of $2-5 \%$. The soils are very sandy in the top horizons. Particle size analysis of three major soils (Table 1) shows that topsoil $(0-30 \mathrm{~cm})$ sand contents are $>80 \%$. 
Particle size distribution of topsoils of some profiles over granite

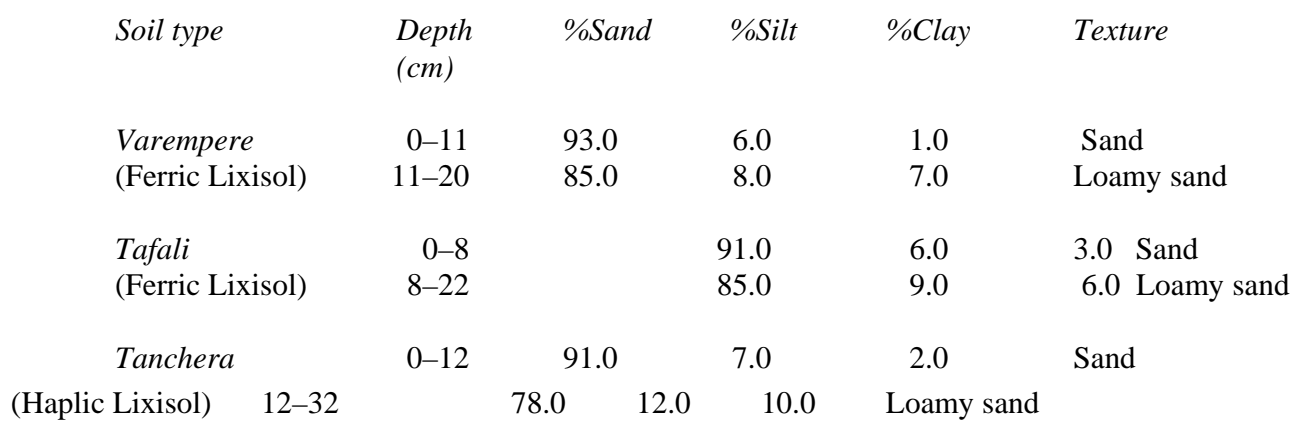

The predominant textures are sand and loamy sand. The sandy topsoils are highly susceptible to erosion if they are left without any protective cover. Inappropriate land use practices such as leaving the soil surface bare facilitate the process of degradation (Stocking \& Elwell, 1976; Quansah, 1981; Quansah, Baffoe-Bonnie \& Agyei, 1990; Quansah et al.,1997). Within a 24-year period (from 1969-1993), topsoil thickness of the three major soil types examined decreased from a range of $35-75 \mathrm{~cm}$ to $20-45 \mathrm{~cm}$. The percentage reduction is over $35 \%$ (Table 2). Elsewhere within the zone, about $120 \mathrm{~cm}$ of soil above the unweathered parent rock was lost through erosion (Asiamah, 1995).

TABLE 2

Changes in topsoil thickness of selected profiles within a 24-year period

$\begin{array}{lccc}\text { Soil type } & \begin{array}{c}\text { Topsoil } \\ \text { thickness }(\mathrm{cm}) \\ \text { in } 1969\end{array} & \begin{array}{c}\text { Topsoil } \\ \text { thickness }(\mathrm{cm})\end{array} & \text { \% Change } \\ \text { in } 1993 & \\ \text { Varempere } & 35 & 22 & 37 \\ \text { Tafali } & 50 & 32 & 36 \\ \text { Tanchera (1)* } & 75 & 20 & 73 \\ \text { Tanchera (2)* } & 75 & 45 & 40\end{array}$

* Numbers refer to the same soil type with two different soil profiles examined.

The soils over Birrimian phyllite are associated with hilly terrain, which are generally rolling (10-15\%) and steep (>30\% slope). These soils are clayey and more cohesive than the sandy soils over granite. The surfaces are rocky on the hill summits and slopes, compacted and sealed in the lower slopes as a result of the heavy textures. The erosion process, in this case, is accelerated by high run-off as a result of the steep slopes, rocky and sealed surfaces.

\section{The influence of human activities}

Farming and domestic fuel production are major land use practices, which have a direct effect on land degradation in the study area. These land uses are the first step to land degradation since their initiation destabilizes the land through the removal of the protective vegetative cover or inappropriate management practices.

Farming is the major activity that is responsible for inducing land degradation because it involves, firstly, extensive vegetation clearing which exposes the soil and, secondly, several improper farm practices which accelerate degradation. The improper farm practices include burning of organic material during land preparation, total crop harvesting and inadequate manuring and fertilizer use. All forms of organic material, particularly crop stumps left in the soil from the previous harvest, are dug out, gathered and burnt. Burning not only deprives the soil of its source of nitrogen, phosphorus and sulphur supply but also affects its physical, chemical and biological properties negatively (Agboola, 1993). Such farmlands are left very 'neat' and bare as a result. Among the reasons given for burning, the major ones are clearing the land for cultivation and seed germination (Table 3). These two reasons are, however, complementary and confirmed by $23.8 \%$ of respondents who gave the two as reasons for burning. The objective of clearing the land is mainly to remove any impediment that may prevent the seeds from germinating. 
1. No reason given

2. To make land clear

$\begin{array}{rr}41 & 19.5 \\ 44 & 21.0 \\ 1 & 0.5 \\ 45 & 21.4 \\ 10 & 4.8 \\ 1 & 0.5 \\ 2 & 1.0 \\ 50 & 23.8 \\ 1 & 0.5 \\ 1 & 0.5 \\ 14 & 6.7 \\ & \\ 210 & 100.0\end{array}$

Total

Total crop harvesting involves the removal of both crop and residue, thus, leaving no plant material on the surface for decomposition. Major crops totally harvested for various purposes are millet, guinea corn (sorghum), groundnut and cowpea. While millet and guinea corn are harvested for fuel, cowpea and groundnuts, are mainly for animal feed (Table 4).

TABLE 4

Crops residues and their various uses

Crop residue Fuel Animal feed Burnt Left on farm

Percent of respondents per use category

$\begin{array}{lrrrr}\text { Millet } & 96 & 1 & - & 1 \\ \text { Guinea corn } & 87 & 1 & - & - \\ \text { Maize } & - & 1 & - & 2 \\ \text { Cowpea/bean } & 1 & 54 & - & 1 \\ \text { Bambara bean } & - & 3 & 6 & 10 \\ \text { Groundnut } & 7 & 26 & - & - \\ \text { Rice } & - & 2 & 11 & 5\end{array}$

Domestic energy supply and demand are directly associated with the natural environment, particularly in the rural sector. Wood is most preferred, if available, as an energy source to others which are normally used as supplements (Senayah, 1994). However, in the Bawku area, crop stalks, mainly from sorghum and millet, are the major sources of energy used by $95 \%$ of the respondents. Other sources, in descending order of preference, are wood (88\%), cowdung (47\%) and charcoal (10\%). Every household uses more than one source of energy (Table 5). The use of crop stalks as a major source of energy further empha-sizes the practice of total crop harvesting. This culture leaves farm-lands bare and exposes them to the elements during the off-farm season and other agents of degradation.

TABLE 5

Combinations of domestic energy sources used in the Bawku area

$\begin{array}{lcr}\begin{array}{l}\text { Energy source } \\ \text { combinations }\end{array} & \begin{array}{c}\text { No. of } \\ \text { respondents }\end{array} & \% \\ \text { Wood + crop stalks } & 25 & 41.6 \\ \text { Wood + crop stalks + cow dung } & 22 & 36.6 \\ \text { Crop stalks + cow dung } & 4 & 6.6 \\ \text { Wood + crop stalks + charcoal } & 3 & 5.0 \\ \text { Crop stalks only } & 3 & 5.0 \\ \text { Wood + charcoal + cow dung } & 2 & 3.3 \\ \text { Wood + charcoal } & 1 & 1.6\end{array}$


Animal manure, especially cow dung, is the major source of soil fertility improvement in the study area. However, it is grossly inadequate since it also serves as a source of fuel, a major competing use. Thus, apart from physical degradation, soil nutrient impoverishment is also a major constraint (Senayah, 1994). Analytical data of soil samples from 14 continuously cultivated sites show low levels of organic matter $(\mathrm{OM})$, nitrogen $(\mathrm{N})$, phosphorus $(\mathrm{P})$ and potassium (K) (Table 6).

TABLE 6

Chemical analyses of soils from 14 selected farms in the Bawku area

\begin{tabular}{|c|c|c|c|c|c|c|c|c|c|c|c|c|c|c|c|}
\hline & & & & & & & & & & \multicolumn{6}{|c|}{ Selected farms } \\
\hline Parameter & Depth (cm) & 1 & 2 & 3 & 4 & 5 & 6 & 7 & 8 & 9 & 10 & 11 & 12 & 13 & 14 \\
\hline $\mathrm{OM}$ & $0-10$ & 0.7 & 1.3 & 0.9 & 0.8 & 0.8 & 2.0 & 2.6 & 1.4 & 0.4 & 0.4 & 0.5 & 3.0 & 1.3 & 0.8 \\
\hline (\%) & $10-30$ & 0.6 & 1.1 & 1.0 & 0.8 & 0.4 & 1.3 & - & 0.8 & 0.3 & 0.6 & 0.6 & 1.5 & 1.1 & 0.6 \\
\hline $\begin{array}{l}\mathrm{N} \\
(\%)\end{array}$ & $\begin{array}{r}0-10 \\
10-30\end{array}$ & $\begin{array}{l}0.02 \\
0.01\end{array}$ & $\begin{array}{l}0.02 \\
0.01\end{array}$ & $\begin{array}{l}0.01 \\
0.01\end{array}$ & $\begin{array}{l}0.01 \\
0.01\end{array}$ & $\begin{array}{l}0.01 \\
0.01\end{array}$ & $\begin{array}{l}0.02 \\
0.02\end{array}$ & $\begin{array}{r}0.01 \\
-\end{array}$ & $\begin{array}{l}0.02 \\
0.02\end{array}$ & $\begin{array}{l}0.01 \\
0.01\end{array}$ & $\begin{array}{l}0.01 \\
0.01\end{array}$ & $\begin{array}{l}0.01 \\
0.01\end{array}$ & $\begin{array}{l}0.10 \\
0.07\end{array}$ & $\begin{array}{l}0.11 \\
0.04\end{array}$ & $\begin{array}{l}0.06 \\
0.04\end{array}$ \\
\hline $\begin{array}{l}\mathrm{P} \\
\text { (mg/kg soil) }\end{array}$ & $\begin{array}{r}0-10 \\
10-30\end{array}$ & $\begin{array}{l}3.10 \\
3.87\end{array}$ & $\begin{array}{l}9.00 \\
6.65\end{array}$ & $\begin{array}{l}1.25 \\
0.65\end{array}$ & $\begin{array}{l}0.70 \\
0.30\end{array}$ & $\begin{array}{l}1.55 \\
0.30\end{array}$ & $\begin{array}{l}1.50 \\
0.50\end{array}$ & $\begin{array}{r}0.25 \\
-\end{array}$ & $\begin{array}{r}11.00 \\
3.60\end{array}$ & $\begin{array}{l}5.08 \\
0.77\end{array}$ & $\begin{array}{l}1.20 \\
0.85\end{array}$ & $\begin{array}{l}1.80 \\
3.30\end{array}$ & $\begin{array}{r}15.50 \\
0.46\end{array}$ & $\begin{array}{l}9.60 \\
0.77\end{array}$ & $\begin{array}{l}3.22 \\
0.98\end{array}$ \\
\hline $\begin{array}{l}\mathrm{K} \\
\text { (mg/kg soil) }\end{array}$ & $\begin{array}{r}0-10 \\
10-30\end{array}$ & $\begin{array}{l}20.00 \\
15.00\end{array}$ & $\begin{array}{l}32.50 \\
22.50\end{array}$ & $\begin{array}{l}35.00 \\
22.50\end{array}$ & $\begin{array}{l}32.50 \\
15.00\end{array}$ & $\begin{array}{l}55.00 \\
22.50\end{array}$ & $\begin{array}{l}27.50 \\
25.00\end{array}$ & $\begin{array}{r}15.00 \\
-\end{array}$ & $\begin{array}{l}45.00 \\
45.00\end{array}$ & $\begin{array}{r}20.00 \\
7.50\end{array}$ & $\begin{array}{r}10.00 \\
5.00\end{array}$ & $\begin{array}{l}10.00 \\
10.00\end{array}$ & $\begin{array}{l}10.00 \\
17.50\end{array}$ & $\begin{array}{r}4.00 \\
15.00\end{array}$ & $\begin{array}{l}35.00 \\
30.00\end{array}$ \\
\hline
\end{tabular}

Except for a few of the selected farms with moderate levels (2.0-3.0\%) of OM in the top $10 \mathrm{~cm}$, most of the farms have very low $(<1.0 \%$ ) levels within a $30-\mathrm{cm}$ depth. Since OM is the main source of nutrient supply in most subsistence farms (Asiamah, 1995), the observed very low levels are reflected in the low to very low P (3.0-6.5 $\mathrm{mg} / \mathrm{kg}$ soil) and $\mathrm{K}$ levels ( $<50 \mathrm{mg} / \mathrm{kg}$ soil) at most of the sites.

\section{The process of degradation}

The process of land degradation is really an interaction of physical and human elements. The physical comprises resources of the environment while the human elements are the human needs and activities undertaken in the environment to satisfy these needs. The characteristics of the physical elements in the environment play important roles in the process of degradation. In the selected communities, it was observed that soil characteristics such as those developed over granite and steep slopes occurring in the phyllite area are major physical factors influencing soil erosion. Climate, largely through high intensity rainfall, also plays a major role in causing soil erosion. Rates of 200 $\mathrm{mm} / \mathrm{h}$ sustained for short periods are common in the interior savanna zone of Ghana, particu-larly in the Sudan savanna portion, where Bawku is located (Quansah, Baffoe-Bonnie \& Asiamah, 1989). This situation can also be likened to the interior savanna of northern Nigeria, which has conditions similar to the interior or northern savanna of Ghana. Peak intensities of $120-160 \mathrm{~mm} / \mathrm{h}$ recorded in the savanna of northern Nigeria tend to break up soil aggregates, compact and seal the soil surface, decrease infiltration thus culminating in increased run-off and soil erosion (Kowal \& Kassam, 1978).

On the human side, the needs of the high population particularly food, shelter and energy, are the main driving forces for using the land for farming, livestock grazing and energy production. The physical impact of these is considered in terms of the nature of soil surface conditions, which is shown by the presence of abundant stones, iron and quartz gravel with ironpan exposures, sealed and crusted or compact soil surface and loose sandy surfaces. From the spatial distribution of these features (Fig. 2), about $50 \%$ of the study area which was catego-rized as slightly degraded and highly suscept-ible to erosion on account of the occurrence of loose sandy topsoil, is the most cultivated land. If erosion prevention mea-sures are not seriously considered such areas can become severely degraded, thus, further reducing the quality of the soils to the marginal status. 


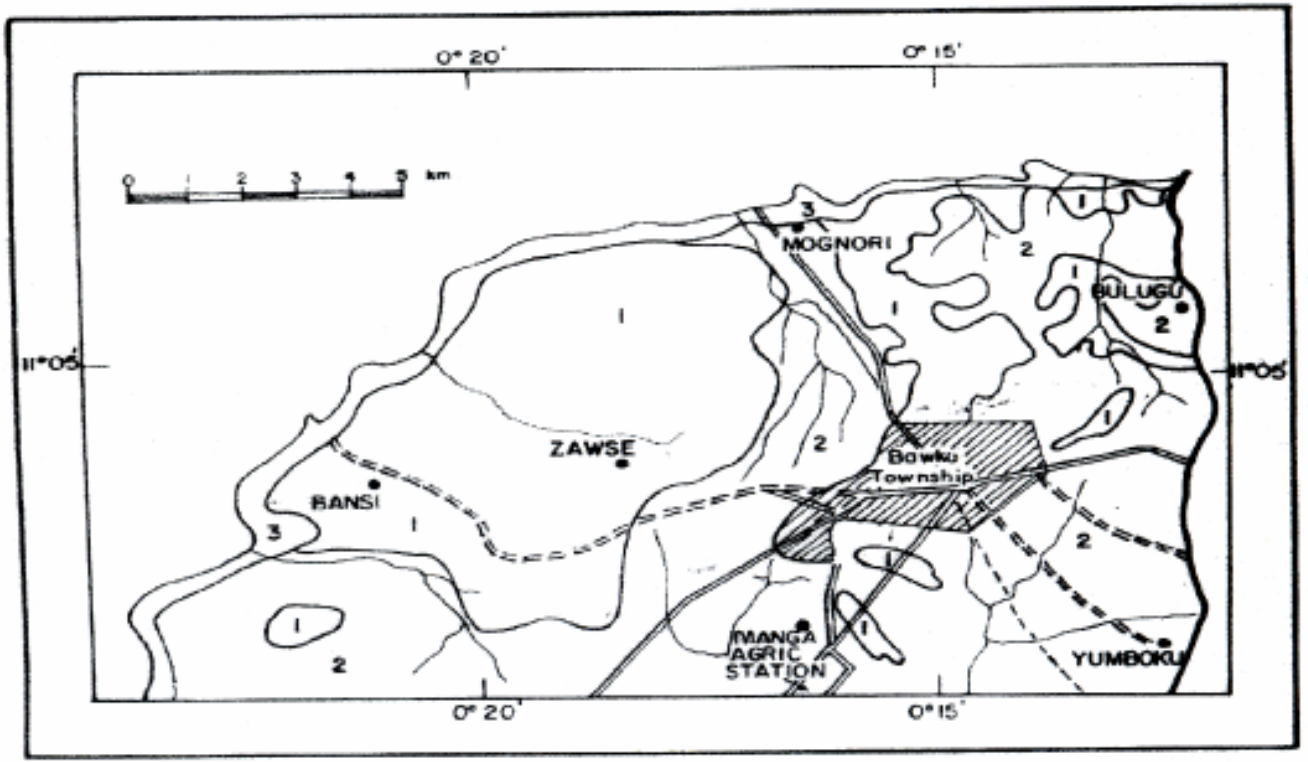

Fig. 2. Spatial distribution of land degradation features int he selected communities

About $45 \%$ of the remaining lands are either marginal or uncultivable. Adu $(1969,1972)$ rated some of these lands as slightly degraded and with moderately deep solum $(50-100 \mathrm{~cm})$ but they have now become either marginal or unsuitable for any meaningful agricultural activity as a result of improper land use practices (Senayah, 1994).

\section{Effect on crop production}

Crop production as a means of livelihood is very important in an agricultural area like Bawku. Low crop yields are common with $94 \%$ of respondents observing a progressive decline and attributing this to soil degradation. Apart from this, $81 \%$ of respondents considered low rainfall, $76 \%$ continuous use of the same piece of land, and $42 \%$ lack of fertilizer use as factors that have resulted in reduced crop yields. Observation shows that rainfall is unreliable and low. Mean annual rainfall for a period 40 years (1961-2000) at Manga-Bawku is appro-ximately 967 mm with annual totals over the same period, ranging from 568-1374 mm (Table 7). About 15 out of the 40 years have annual totals below the mean annual rainfall. Analyses of the mean monthly rainfall, on a decade basis, shows the fluctuating pattern in rainfall amounts (Fig. 3) especially in the growing period from April to October. As a result, crops suffer from moisture stress when there is an appreciable break in rainfall. This is further aggravated by soil characteristics such as loose sandy topsoils, shallow soil depth and gravelly topsoils.

TABLE 7

Annual rainfall amounts from 1961-2000 for the Manga-Bawku area

$\begin{array}{cccc}\text { Year } & \begin{array}{c}\text { Annual rainfall } \\ (\mathrm{mm})\end{array} & \text { Year } & \begin{array}{c}\text { Annual rainfall } \\ (\mathrm{mm})\end{array} \\ 1961 & 772.3 & 1981 & 741.4 \\ 1962 & 1293.3 & 1982 & 961.7 \\ 1963 & 993.1 & 1983 & 567.6 \\ 1964 & 943.8 & 1984 & 848.2 \\ 1965 & 648.9 & 1985 & 784.2 \\ 1966 & 1019.3 & 1986 & 1226.9 \\ 1967 & 1159.3 & 1987 & 1221.6 \\ 1968 & 1060.7 & 1988 & 1374.2 \\ 1969 & 1066.6 & 1989 & 1059.4 \\ 1970 & 1040.0 & 1990 & 810.3 \\ 1971 & 1018.2 & 1991 & 1035.5 \\ 1972 & 873.9 & 1992 & 854.0 \\ 1973 & 1037.3 & 1993 & 693.0 \\ 1974 & 962.3 & 1994 & 1025.4 \\ 1975 & 880.4 & 1995 & 957.9 \\ 1976 & 802.8 & 1996 & 1038.9 \\ 1977 & 988.4 & 1997 & 914.1\end{array}$



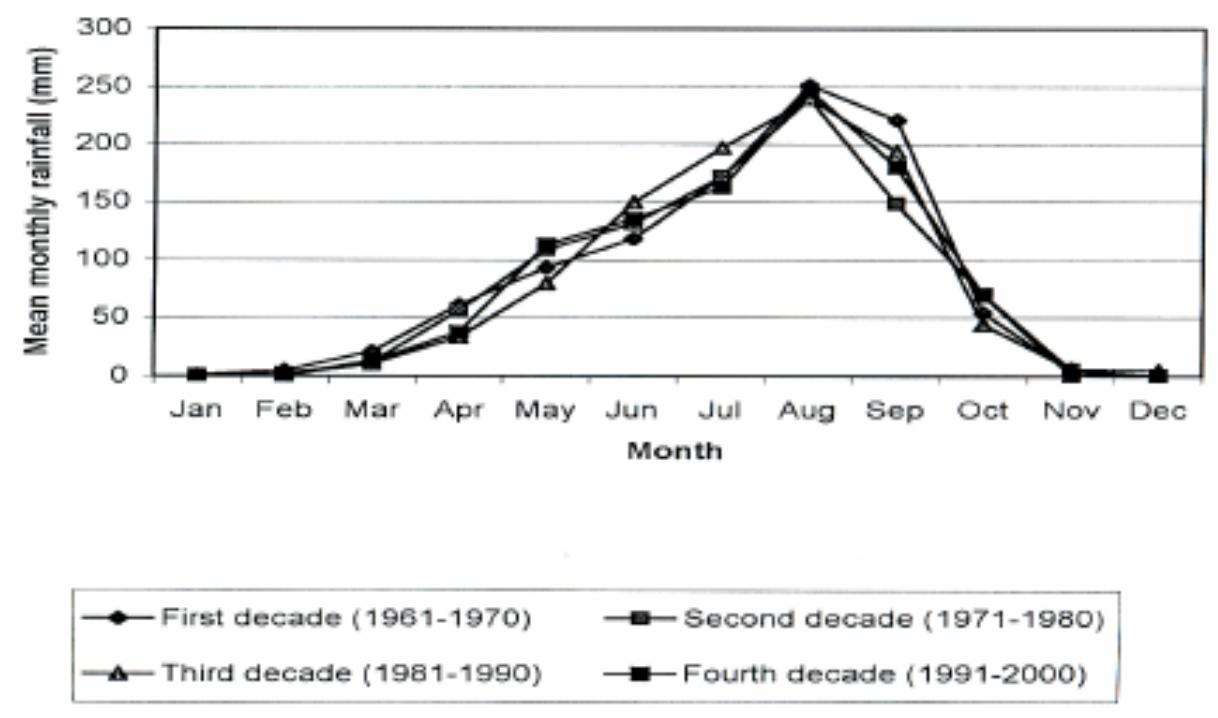

Fig. 3. Mean monthly rainfall distribution on a decade basis

The continuous use of the same piece of land has eliminated the traditional fallow system as a means of soil fertility restoration. In the study, $91 \%$ of respondents do not practise fallow, while $8 \%$ practise fallow for periods between 1-3 years. The decline in yield is supported by a comparative study under on-farm trials and normal farmers' practices where the former comprises NPK fertilizer treatment and the latter household and animal manure. Farmers' practices show a decline in the yields of most of common crops grown in the area compared to management under the on-farm trials (Fig. 4). Crop yields obtained under farmers' practices are mostly below $50 \%$ of the on-farm trials.

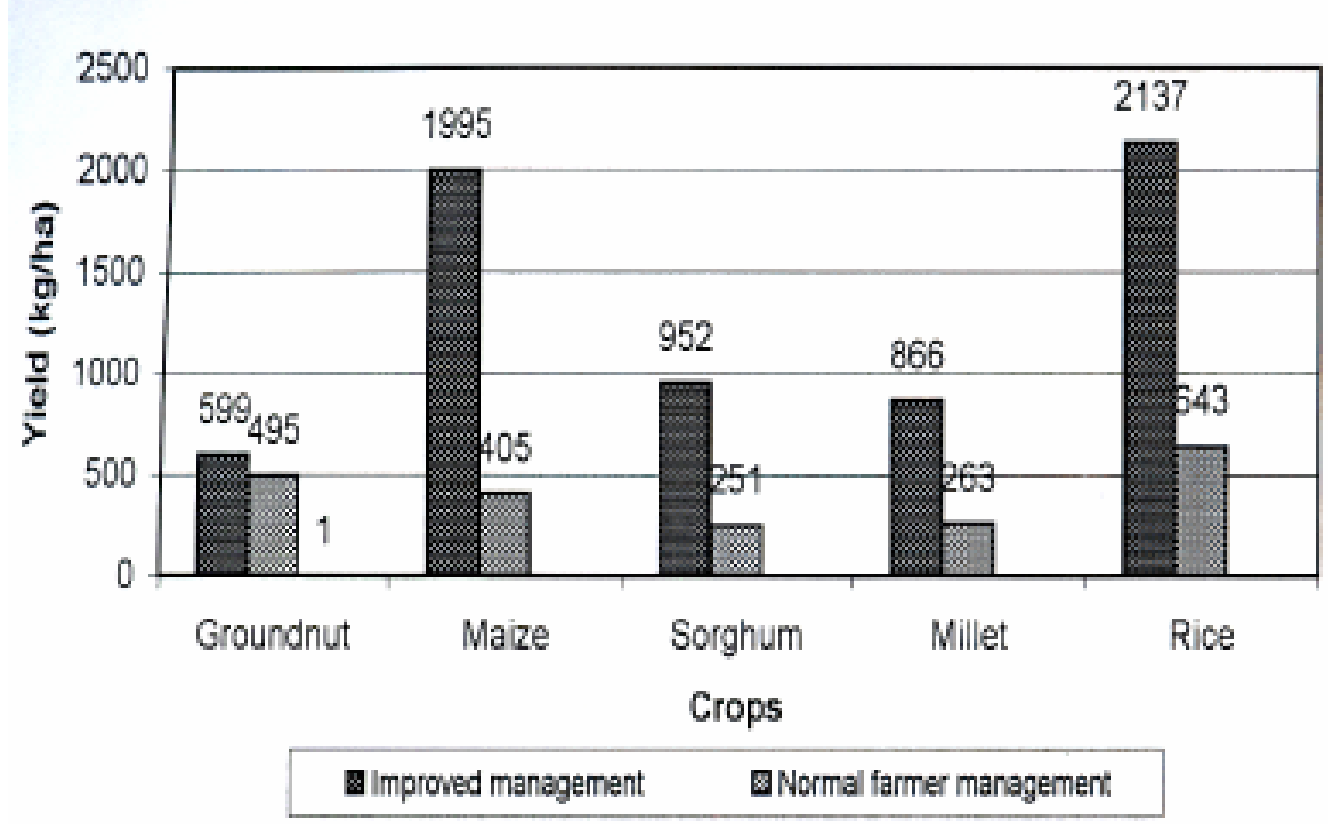

Fig. 4. Crop yields under different management practices 


\section{Conclusion}

Land degradation is proven to be a serious threat to the natural resource base in the Bawku area and the Sudan savanna agro- ecological zone in general. Soil erosion is the most observed form of degradation. The key observed factors influencing the degra-dation are soil texture, steep slopes, high rainfall intensities, exposed soil surfaces and inappropriate farm practices. Low soil fertility resulting in low crop yields is a direct consequence of degradation. Degradation is caused not only by farming activities but others that also supply basic human needs such as domestic energy production. Attempts at solving the problem of degrada-tion should have a holistic approach. By this, provision should be made for all aspects of basic community needs, which are soil-dependent since their neglect will still result in increased degradation. These activities should include soil improvement for increased crop yields, woodlots for domestic energy production and housing materials and feed production for livestock.

Pressure on land also plays a major role as a result of the high population density and the continued reduction of good lands by degradation. Therefore, apart from improv-ing soil conditions, identification of other incomegenerating activities that could ameliorate land use pressure will be very useful.

\section{References}

Adu S. V. (1969). Soils of the Navrongo-Bawku Area, Upper East Region, Ghana. Memoir No. 5, Soil Research Institute, Kumasi.

Adu S. V. (1972). Eroded savanna soils of the Navrongo - Bawku area. Northern Ghana. Ghana Jnl agric. Sci. 5: 312.

Agboola A. A. (1993). Organic fertilizer, the key to sustainable agricultural production in Africa. Report on workshop on policies, local resources and usage of fertilizers in Africa. SOFERNET Paper No. 9. Dakar, Senegal.

Agboola A. A. and Aiyelari E. A. (2000). Land degradation and soil fertility decline in Africa. Afr. Soils 31: 35-53.

Asiamah R. D. (1995). Nutrient depletion and soil mining in sub-Saharan Africa agriculture. In Proceedings of Workshop on National Soil Reference Collections (NASREC). (N. J. Batjes, J. H. Kaufman and O. C. Spaargaren, ed.) 3: 87-93.

Asiamah R. D. and Quansah C. (1992). Soil management for the improvement of agricultural production in Ghana. Rapport sur les ressources en sols du Monde 69. FAO, Rome.

Asiamah R. D., Quansah C. and Dedzoe C. D. (2000). Soil degradation: Management and rehabilitation in Ghana An overview report, 89-101. In Proceedings FAO/ISCW Expert Consulta-tion on Management of degraded soils in Southern and East Africa (MADS - SEA), Pretoria, South Africa. 8-22 Sep. 2000.

Bouyoucous G. J. (1962). Hydrometer method improved for making particle size analysis of soils. Agron. 54: 464465.

DGRD (1992). A socio-economic survey in the Upper East Region with reference to drought and desertification control in Ghana. Department of Geography and Resource Development (DGRD), Legon. A report submitted to the Environmental Protection Council of Ghana.

Kowal J. M. and Kassam A. H. (1978). Agriculture Ecology of Savanna. A study of West Africa.

Lal R., Mokma D. \& Lowery B. (1998). Relation between soil quality and erosion. In Soil quality and soil erosion. (R. Lal, ed.), pp. 237-257. CRC Press. Boca Raton. Fl.

Lowery B., Hart G. L., Bradford J. M., Kung K - J. S. and Huang. C. (1998). Erosion impact on soil quality and properties and model estimates. In Soil quality and soil erosion. (R. Lal. ed.), pp. 75-93. CRC Press, Boca Raton, Fl.

Nelson O. W. and Sommers. L. E. (1982). Total carbon, organic carbon and organic matter. In Methods of Soil Analysis: Part 2. Chemical and Microbiological Properties, 2nd edn. (A. L. Page, R. H. Miller and D. Z. Keeney, eds.). Ameri-can Society of Agronomy, Madison (Agronomy 9).

Norton D., Shainberg I., Cihacek L. and Edwards J. H. (1998). Erosion and soil chemicalproperties. In Soil quality and soil erosion.( R. Lal, ed.), pp. 39-55. CRC Press, Boca Raton, Fl.

Oldeman L. R. (1994). The global extent of soil degradation. In Soil resilience and land use. (D. J. Greenland and T. Szaboles, ed.). Wallingford, UK, Commonwealth Agricultural Bureau International.

Olson K. R., Mokma D. L., Lal R., Schumacher T. E. and Lindstrom, M. J. (1998). Erosion impacts on crop yield for selected soils of the North Central United States. In Soil quality and soil erosion. (R. Lal, ed.), pp. 259-283. CRC Press, Boca Raton, Fl.

Quansah C. (1981). The effect of soil type, slope, rain intensity and their interactions on splash detachment and transport. J. Soil Sci. 32: 215-224.

Quansah C., Baffoe-Bonnie E. and Asiamah R. D. (1989). Soil erosion in Ghana and strategies for conservation. A paper presented at the African Ministerial Conference on the environment (RCU/SOFERNET) and soil conservation strategy for Africa. Accra, Ghana. 28 - 30 August, 1989.

Quansah C., Baffoe-Bonnie E. and Agyei F. (1990). Runoff and soil loss under four legumes. In Land use and the environment. (M. A. Zobisch, ed.). Proc. Soil Sci. Soc. Ghana. 11: 67-75. 
Quansah C., Ampontuah E. O., Kyei-Baffour N. and Asare E. (1997). The effect of soil cover on soil loss and runoff. In Proceedings of Workshop on erosion-induced loss in soil productivity. Kumasi - Ghana. Dec. 8-11, 1997. (R. Sant' Anna, C. Quansah and R. D. Asiamah, ed.), pp. 53-68.

Sant' Anna R. (1993). Environmental and natural resources management for sustainable agricultural development in Africa: A critical challenge PWU. Los Angeles, California, USA.

Sant' Anna R. (2001). Soil degradation and crop production in arid regions of Africa. Paper presented at the 4th Session of the Inter-African experts committee on African soils. Accra, Ghana. 6-8 Aug, 2001.

Senayah J. K. (1994). Characterization of land degradation in a northern savanna environment: The Bawku area. (MPhil Thesis.) Dept. of Geography and Resource Development, Univ. of Ghana, Legon.

Sherr J. S. (1999). Soil degradation: A threat to developing-country food security by 2020? Food, Agriculture and the Environment Discussion Paper 27. International Food Policy Research Institute, Washington D. C. USA.

Sherr S. J. and Yadav S. (1996). Land degradation in the developing world: implications for food, agriculture and the environment to 2020. IFPRI - Food, Agricultural and Environment Discussion Paper 14. 36 pp.

Shetty S. V. R., Debrah S. K. and Renard C. (1995). Technology development, testing and transfer: An overview of ICRISAT's Experience in semi-arid Africa.In Proc. of Workshop on Moist Savannas of Africa: Potentials and constraints for crop production. Cotonou, Benin. Sept 19-23, 1994.

Stocking M. A. and Elwell H. A. (1976). Vegetation and erosion: a review. Scot. Georgl. Mag. 92 (1): 4-16.

Stoorvogel J. J. and Smaling E. M. A. (1990). Assessment of nutrient depletion in sub-Saharan Africa, 1983-2000. Report No. 28. Wageningen, The Netherlands. Winand Starling Center for Integrated Land, Soil and Water Research.

UNSO. (1986). Essentials of the Problems of Desertification and Review of on-going and proposed activities to implement the Plan of Action to Combat Desertification in Ghana. (United Nations Sudano - Sahelian Office).

Van Reeuwijk L. P. (ed.) (1986). Procedures for soil analysis. Technical Paper 9. International Soil Reference and Information Center (ISRIC), Wageningen, The Netherlands. 